\title{
Aggression in late childhood and in early adolescence in Slovenia: two-wave cohort study
}

\author{
Ana Kozina \\ Educational Research Institute, Ljubljana, Slovenia
}

BACKGROUND

The present study investigated age differences in trait aggression in the period of late childhood and early adolescence that are important for assessment of the aggression levels that are not in line with expected developmental trends and are in need of intervention. Additionally the authors present the time trends from measurement of aggression and its subtypes at two time points.

\section{PARTICIPANTS AND PROCEDURE}

The authors focus on specific subtypes of aggression relevant for the Slovenian context and for the development period. We used the LA aggression scale (general trait aggression and four factors: physical aggression, verbal aggression, internal aggression and aggression towards authority) as a measure of aggression in two age groups, 10-year-olds $(n=4,351)$ and 14-year-olds $(n=4,043)$, at two time points (in 2007 and in 2011).
RESULTS

The results show significant cross-sectional differences in the level of aggression. Older participants exhibit higher levels of general aggression as well as all four aggression types (also in a cohort design). The findings are aligned with contemporary research on personality development stressing greater stability after the period of adolescence. The time-related trends show a significant decrease in physical aggression and an increase in internal aggression from 2007 to 2011 in both observed age groups.

\section{CONCLUSIONS}

The implications of the findings are discussed, and in line with the results early intervention is supported.

KEY WORDS

children; aggression; cohort study; early adolescents

CORResponding AUthor - Ana Kozina, Ph.D., Educational Research Institute, Gerbičeva 62, 1000 Ljubljana, Slovenia, e-mail: ana.kozina@pei.si

AUthors' CONTRIBUtion - A: Study design - B: Data collection - C: Statistical analysis - D: Data interpretation .

E: Manuscript preparation · F: Literature search · G: Funds collection

TO CITE THIS ARTICLE - Kozina, A. (2017). Aggression in late childhood and in early adolescence in Slovenia: two-wave

cohort study. Current Issues in Personality Psychology, 5(1), 32-40.

RECEIVED 13.05.2016 · REVIEWED 14.06.2016 · ACCEPTED 11.11.2016 · PUBLISHED 28.02.2017 


\section{BACKGROUND}

Aggression is behaviour the intention of which is to cause harm to oneself or another person, or behaviour that actually causes it (Huesmann, 1994). In the Big Five personality model aggression (angry hostility) is a trait facet of neuroticism (Matthews, Deary, \& Whiteman, 2009). Trait theorists have long been interested in individual differences in social behaviour, including aggression (Matthews et al., 2009). Due to aggressions' high stability (Huesmann, Eron, Lefkowitz, \& Walder, 1984; Loeber \& Hay, 1997; Olweus, 1979; Overton, 2004) the research on developmental (comparisons of aggression between different age groups) and time-related trends (comparisons of aggression at different points in time) of trait aggression is of great importance for identification of steps that precede the negative outcomes of aggressive behaviour (short term and long term) (Card, Stucky, Sawalani, \& Little, 2008; Huesmann, Dubow, \& Boxer, 2009). Individual develops a characteristic level of aggressiveness which remains relatively stable over situations and in time (Huesmann et al., 1984). This does not mean that the characteristic amount and forms of aggression do not change in time (Eron, Huesmann, Brice, Fischer, \& Mermelstein, 1983). Such change is the subject of the present paper.

In the present study we examined age- and time-related differences in late childhood and early adolescence of different types of aggression as proposed by Vitaro, Brendgen and Barker (2006). The paper addresses age and time differences of direct aggression (physical and verbal) and two specific types of aggression relevant for this developmental period (especially early adolescence) and our cultural surroundings: internal aggression and aggression against authority. Direct aggression is aggression directed towards important others, oneself or objects in a way that the intention is obvious to others. Aggression directed towards important others (e.g. teachers, classmates, parents) can take a physical or verbal form (Flannery, Vazsonyi, \& Waldman, 2007). Physical aggression includes physical acts in order to harm others (e.g. hitting, pushing...). Verbal aggression (Choynowski, 1995) expresses rejection, threat, criticism, and derogation, cursing and negative valuation of the person attacked. Direct aggression is the one linked to severe negative outcomes (Archer \& Coyne, 2005; Connor, 2002 ) at the individual and the community level (lower educational achievement (Connor, 2002; Flannery et al., 2007; Vršnik Perše, Kozina, \& Rutar Leban, 2011), difficulties in social (Card et al., 2008) and cognitive functioning, anxiety, etc. (Connor, 2002; Kozina, 2016; Vitaro et al., 2006)). Aggression towards authority is aggression directed towards figures of authority (e.g. teachers, parents). Aggression against authority can be understood also as nonconformity (Choynowski,
1995). It was included because of the important role of authority figures in late childhood and early adolescence (Marjanovič Umek \& Zupančič, 2004). Internal aggression is aggression directed at oneself in the form of feelings of guilt, bad mood and pessimism (Čotar Konrad, 2005). Internal aggression is also related to suicidal behaviour (Alsaker \& Dick-Niederhauser, 2008), which is frequent in eastern European countries including in Slovenia (Tomori, Kienhorst, de Wilde, \& van den Bout, 2001).

The analyses of age- and time-related differences in aggression can help in developing the intervention and prevention models in order to diminish these consequences and improve the possibilities for children and adolescents.

The literature reviews on the development of aggression have produced mixed results. Some studies have revealed a decline (Hyde, 1984; Park \& Salby, 1983, both as cited in: Hudley, 1993; Cairns, Cairns, Neckerman, Ferguson, \& Gariepy, 1989), some others growth over years (Whiting \& Whiting, 1975, as cited in: Hudley, 1993), and the third group of studies show that individuals in their middle and late childhood are more aggressive than younger and older individuals (Huesmann, 1994), indicating that the period of middle and late childhood is in need of further research. In our study we will focus on two age groups, 10-year-olds (late childhood) and 14-year-olds (early adolescence), representing the development of aggression from late childhood to early adolescence.

The growth or decline of aggression depends on the type of aggression observed, which confirmed the need of observing developmental and time-related trends separately for each subtype. The development of aggression takes place in the direction from direct forms to indirect ones. Studies (Connor, 2002; Cairns et al., 1989; Vitaro et al., 2006; Tremblay, 2000) showed a decline in physical and verbal aggression (as two types of direct aggression) over years and a rise in indirect aggression (Romano, Tremblay, Boulerice, \& Swisher, 2005). More specifically physical aggression according to cross sectional studies declines from 8 to 18 years of age and verbal aggression increases from 8 to 11 years of age and then slightly declines from 15 to 18 years of age (Bjorkqvist, Lagerspetz, \& Kaukiainen, 1992). Some researchers (Tremblay et al., 2004) put the increase of verbal aggression and decrease of physical aggression at an even earlier age, which is four years old or even two (Tremblay, 2000). Developmentally children in their earliest period use physical aggression because they are not yet able to express aggression in other ways (Vitaro et al., 2006). Through development of their verbal and social skills children first start using verbal aggression and later when they are increasingly able to control their own feelings and follow the rules of acceptable behaviour they add indirect aggression (Vitaro et al., 2006). Clinical researchers have reached similar conclusions (Connor, Steingard, Cunningham, 
Anderson, \& Melloni, 2004); they have established that children and adolescents with lower verbal cognitive skills or any other speech impediments that prevent them from verbalizing a conflict more often use physical aggression compared to others who do not have impediments or lower verbal cognitive skills. This shift has also been observed in studies which monitored the aggression of twins and established that increased physical aggression leads to increased indirect aggression, whereas vice versa this was not the case (Vitaro et al., 2006).

As evident from the literature review the complexity of aggression types presents a challenge for analysing age- and time-related trends of aggression. The current study aims at:

- Analyses of age-related differences in aggression between periods of late childhood and early adolescence that could be attributed to the developmental increase or decrease. We will compare aggression of two age groups (10-year-olds vs. 14-year-olds) using the same aggression measurement scale. In order to gain higher generalizability we will compare age differences at two time points (2007 and 2011). Additionally the 10-yearolds from 2007 are in four years' time (i.e. in 2011) 14-year-olds, which means they are the same generation, enabling us to use a longitudinal cohort design. A cohort study is a compromise between longitudinal and cross sectional studies which enables observations of a generation of participants over a period of time (the sample of participants of one generation is over a specific time period, in our case a period of four years, compared with a new sample of the same generation in a measured characteristic), whereby effects of different generations on the differences in the observed variable are diminished. Additionally, age changes (from 10-year-olds to 14-year-olds) will be analysed in a cross-sectional design separately for 2007 and for 2011. Significant changes are expected in the level of aggression between children in 2007 and adolescents in 2011 due to developmentand age-related changes taking place.

- Analyses of time-related trends in aggression (and types of aggression). A comparison of aggression in 10-year-olds from 2007 with 10-year-olds from 2011 and respectively 14-year-olds from 2007 with 14-year-olds from 2011 will serve for the purposes of analysing if and in what way children's/adolescents' aggression changes from 2007 to 2011. In this case the average age of the compared groups stays the same, but there is a difference in the time of measurements. The possible differences in observed phenomena can be interpreted as a result of a change in aggression from 2007 to 2011. In terms of time-related trends significant changes were not expected due to research results from other countries. A research review showed that time-related trends show stability of aggression in time. Research showed that aggressive behaviour in schools did not increase from 1994 to 1999 in Germany (Popp, 2003), in the USA (Small \& Terrick, 2001) or in the UK (Rigby, 2008, as cited in Mugnaioni Lešnik, Koren, Logaj, \& Brejc, 2008).

In Slovenia, to our knowledge studies on developmental and time-related trends have not yet been conducted. The findings will therefore contribute significantly to the research of aggression in Slovenia. There is increasing attention to the possible rise of aggressive behaviour in a school setting, indicating the need to analyse possible time trends. The study adds to the personality research across cultures by providing an insight into aggression development in Slovenia (representing specific eastern European culture, e.g. rates of suicide, level of neuroticism (Musek, 1994)).

\section{PARTICIPANTS AND PROCEDURE}

\section{PARTICIPANTS}

TIMSS (Trends in Mathematics and Science Study) 2007 national study sample (for Slovenia). The study used TIMSS study samples in order to ensure higher representativeness and joint use of TIMSS databases for further research on aggression-related factors. Sampling was multi-level and stratified (regions within Slovenia were set as strata). In total 148 primary schools in Slovenia were randomly sampled (school enrolment and regions have been taken into consideration), and within the selected schools, $4^{\text {th }}$ grade and $8^{\text {th }}$ grade classes were selected randomly, one or two per school. Random sampling was done using WinW3S software (IEA DPC, v. 2006), which was developed especially for this purpose in international TIMSS centres. If parents' permission had been given, the selected school classes were included in the study as a whole. The sample of $8^{\text {th }}$ grade pupils consisted of 260 classes with 4,043 pupils (2,545 male pupils, 2,569 female pupils). Their average age was $13.8(S D=0.4)$ years. The sample of $4^{\text {th }}$ grade pupils consisted of 343 classes with 4,351 pupils (2,621 male pupils, 2,663 female pupils). Their average age was $9.8(S D=0.3)$ years (Japelj Pavešič, Svetlik, Rožman, \& Kozina, 2008).

TIMSS 2011 study sample. The sampling design in the TIMSS 2011 study was similar to the TIMSS 2007 sampling design described above. In order to ensure comparability between regions, the sample was further expanded. 209 primary schools in Slovenia were sampled. The sample of $8^{\text {th }}$ grade pupils consisted of 266 classes with 4,741 pupils (2,274 male pupils, 2,173 female pupils). Their average age was 13.9 $(S D=0.3)$ years. The sample of $4^{\text {th }}$ grade pupils consisted of 243 classes with 4,674 pupils (2,347 male pupils, 2,158 female pupils). Their average age was 9.9 years $(S D=0.3)$ (Japelj Pavešič, Svetlik, \& Kozina, 2012). 


\section{INSTRUMENTS}

The LA (Lestvica Agresivnosti [Aggression Scale]) aggression scale for children and adolescents (Kozina, 2013) consists of 18 self-evaluation items on a Likert type measurement scale (1 - totally disagree, 2 - disagree, 3 - something in between, 4 - agree, 5 - totally agree) measuring general aggression and 4 components of aggression: Physical aggression (e.g. I like to fight), Verbal aggression (e.g. When someone screams at me I scream back), Internal aggression (e.g. Other people often annoy me) and Aggression towards authority (e.g. When teachers tell me what to do I disobey). The components were found to be interrelated $(.31<r<.48)$. The second-order PCA showed that in the background of the structure there is a general aggression component, which is highly loaded with all principal first-order components $(0.729,0.865,0.854,0.842)$. It explains $67.94 \%$ of the total variance of first-order components. The 4-component hierarchical structure has been confirmed with CFA $(R M S E A=0.067, C F I=0.912, T L I=0.897$, $S R M R=0.047)$ for the whole sample. The scale has proved to be psychometrically adequate (reliability: $.72<\alpha>.84$, sensitivity: $r_{\text {average }}=.56$, validity: $r_{L A-B D H I}$ $=.69)$.

\section{PROCEDURE}

The TIMSS study procedure is set in accordance with a precisely specified international schedule. The study is conducted in all participating countries in the same way, i.e. two 36-minute TIMSS achievement sessions for $4^{\text {th }}$ grade and two 45 -minute TIMSS achievement sessions for $8^{\text {th }}$ grade. There is a 10-minute break in between both sessions, and after they are both completed there is a 5 -minute break, followed by a 30-minute TIMSS questionnaire session. After completing the TIMSS questionnaires, participants were given the LA aggression scale, both in 2007 and in 2011. The time allotted for completing the scale was not limited. As was the case in the entire TIMSS study, identification codes were used to ensure anonymity and for the purpose of ethical considerations.

\section{RESULTS}

In the results we firstly present age differences for 2007 and 2011 followed by time differences for both age groups.

\section{AGE DIFFERENCES}

The age differences in aggression (and its components) between 10-year-olds and 14-year-olds are significant in both measurement years (Table 1). Fourteen-year-olds have higher levels of aggression (and its components) compared to 10-year-olds. The effects of these differences on the level of general aggression are moderate. With the age differences one can explain about eight percent of general aggression variance in 2007 and about seven percent in 2011. Aggression towards authority showed the

Table 1

One-way ANOVA for testing the differences in aggression (and aggression components) between different age groups at the same measurement times (separately for 2007 and 2011)

\begin{tabular}{|c|c|c|c|c|c|c|}
\hline & \multicolumn{2}{|c|}{ 10-year-olds } & \multicolumn{2}{|c|}{ 14-year-olds } & \multirow[t]{2}{*}{$F$} & \multirow[t]{2}{*}{$\eta^{2}$} \\
\hline & $M$ & $S D$ & $M$ & $S D$ & & \\
\hline \multicolumn{7}{|l|}{2007} \\
\hline Physical aggression & 10.50 & 5.01 & 12.44 & 4.82 & $387.05^{* * *}$ & .04 \\
\hline Verbal aggression & 9.22 & 4.08 & 11.25 & 3.53 & $710.80^{* * *}$ & .07 \\
\hline Internal aggression & 9.21 & 3.63 & 10.16 & 3.20 & $193.47^{* * *}$ & .02 \\
\hline Aggression against authority & 6.60 & 3.26 & 9.09 & 3.36 & $1414.11^{* * *}$ & .12 \\
\hline General aggression & 35.10 & 13.15 & 42.81 & 12.05 & $858.73^{* * *}$ & .09 \\
\hline \multicolumn{7}{|l|}{2011} \\
\hline Physical aggression & 10.10 & 4.97 & 11.91 & 4.95 & $265.76^{* * *}$ & .03 \\
\hline Verbal aggression & 9.40 & 4.27 & 11.15 & 3.76 & $377.26^{* * *}$ & .05 \\
\hline Internal aggression & 10.02 & 3.78 & 10.79 & 3.31 & $94.26^{* * *}$ & .01 \\
\hline Aggression against authority & 6.80 & 3.18 & 9.29 & 3.45 & $1109.53^{* * *}$ & .12 \\
\hline General aggression & 35.87 & 13.29 & 42.92 & 12.65 & $547.46^{* * *}$ & .07 \\
\hline
\end{tabular}


largest age effect at both measurement times and internal aggression showed the smallest effect at both measurement times.

There are significant differences in aggression (and its components) after four years in the same generation. The effects of these differences are greatest in the component aggression towards authority and smallest in the component internal aggression. With the age differences we can explain eight percent of general aggression variance (Table 2).

\section{TIME DIFFERENCES}

There is a significant decrease in physical aggression and a significant increase in internal aggression in 10- and 14-year-olds from 2007 to 2011. In 14-yearolds there is also a significant increase in aggression

Table 2

One-way ANOVA for testing the differences in aggression (and aggression components) of one generation in four years' time

\begin{tabular}{|c|c|c|c|c|c|c|}
\hline & \multicolumn{2}{|c|}{ 10-year-olds (2007) } & \multicolumn{2}{|c|}{ 14-year-olds (2011) } & \multirow[t]{2}{*}{$F$} & \multirow[t]{2}{*}{$\eta^{2}$} \\
\hline & M & $S D$ & M & $S D$ & & \\
\hline Physical aggression & 10.50 & 5.01 & 11.91 & 4.95 & $183.54^{* * *}$ & .02 \\
\hline Verbal aggression & 9.22 & 4.08 & 11.15 & 3.76 & $554.64^{* * *}$ & .06 \\
\hline Internal aggression & 9.21 & 3.63 & 10.79 & 3.31 & $476.34^{* * *}$ & .05 \\
\hline Aggression against authority & 6.60 & 3.26 & 9.28 & 3.45 & $1477.50 * * *$ & .14 \\
\hline General aggression & 35.09 & 13.15 & 42.92 & 12.65 & $780.21^{* * *}$ & .08 \\
\hline
\end{tabular}

Note. ${ }^{* * *} p<.001$

Table 3

One-way ANOVA for testing the differences in aggression (and aggression components) between the same age groups at different measurement times

\begin{tabular}{|c|c|c|c|c|c|c|}
\hline & \multicolumn{2}{|c|}{2007} & \multicolumn{2}{|c|}{2011} & \multirow[t]{2}{*}{$F$} & \multirow[t]{2}{*}{$\eta^{2}$} \\
\hline & $M$ & $S D$ & $M$ & $S D$ & & \\
\hline \multicolumn{7}{|l|}{ 10-year-olds } \\
\hline Physical aggression & 10.50 & 5.01 & 9.86 & 5.05 & $8.06^{* *}$ & .001 \\
\hline Verbal aggression & 9.22 & 4.08 & 9.09 & 4.37 & 0.49 & .000 \\
\hline Internal aggression & 9.21 & 3.63 & 9.93 & 3.78 & $19.68^{* * *}$ & .003 \\
\hline Aggression against authority & 6.60 & 3.26 & 6.65 & 3.23 & 0.11 & .000 \\
\hline General aggression & 35.10 & 13.15 & 35.06 & 13.72 & 0.00 & .000 \\
\hline \multicolumn{7}{|l|}{ 14-year-olds } \\
\hline Physical aggression & 12.45 & 4.82 & 11.91 & 4.95 & $27.06^{* * *}$ & .003 \\
\hline Verbal aggression & 11.25 & 3.53 & 11.15 & 3.76 & 1.67 & .000 \\
\hline Internal aggression & 10.16 & 3.20 & 10.79 & 3.31 & $86.75^{* * *}$ & .009 \\
\hline Aggression against authority & 9.09 & 3.36 & 9.28 & 3.45 & $7.32^{* *}$ & .001 \\
\hline General aggression & 42.81 & 12.05 & 42.92 & 12.65 & 0.19 & .000 \\
\hline
\end{tabular}


14-year-olds. Older participants exhibit higher levels of general aggression as well of all four aggression types. Cross-sectional results show the same pattern of aggression increase (based on component analyses) in 2007 and in 2011. In both measurement years the differences are greatest in aggression towards authority and smallest in internal aggression. The same pattern of differences can be observed when following, on a generation level, the 10-year-olds from 2007 to 2011. The aggression is higher when they are older, with the entrance into the developmental period of early adolescence, which is aligned with contemporary research on personality development stressing greater stability after the period of adolescence (Donnelan \& Robins, 2009).

The increase in general aggression is in line with the findings of other authors. Longitudinal research (Cairns et al., 1989; Huesmann et al., 1984) has shown a developmental increase in peer-nominated aggression from childhood to adolescence. According to Moffitt (1993) regarding discussions on aggression stability in time, only a small group of individuals exhibit high levels of aggression across time points and for most other individuals aggression is limited to one developmental period, that is adolescence. These results due to the period observed came to us as no surprise. These findings support a common trend in promoting as early intervention as possible when it comes to aggression. These findings will also be used for aggression intervention and prevention.

We were subsequently more interested in the pattern of the increase according to the aggression type's level. The increase is significant in all types of aggression. The largest differences due to age differences could be observed in aggression towards authority. With the age differences one can explain approximately $14 \%$ of total aggression towards authority variance. The increase is in line with the characteristics of the developmental period of the older age group - increased nonconformity (Marjanovič Umek \& Zupančič, 2004). Demands for personal autonomy, as a baseline for nonconformity, increase gradually in childhood and adolescence (Goossens, 2008). In this period we should focus on promoting non-aggressive ways of developing adolescents' autonomy, especially since higher aggression towards authority understood as a form of rebelliousness and nonconformity can, as established by Choynowski (1995), lead to later delinquency.

The second largest increase in aggression from 10-year-olds to 14-years-olds can be observed in verbal aggression (the effect sizes are the second largest in both measurement years). The increase could be explained as being due to maturation; a certain level of verbal abilities has to be present in order to use verbal aggression (Bjorkqvist et al., 1992). This is in line with the expectation that developmentally one would expect a change from gross (e.g. physical) to more refined aggressive strategies (e.g. verbal and indirect aggression) (Bjorkqvist et al., 1992). Younger children who lack verbal skills are likely to use physical aggression preferably (Bjorkqvist et al., 1992). As their verbal skills develop they add direct verbal aggression (measured in our study) and later on with the development of social skills also indirect aggression, using a social network as a means of harming others.

The smallest effect size is in physical aggression. The increase is still significant, but the percentage of explained variance is relatively small: two percent. Some research on the development of physical aggression has confirmed the increase. For instance, Elliot (1994, as cited in Tremblay, 2000) presented results of a longitudinal study indicating an increase in violent offending from 12 to 17 years of age. The increase in aggression can partly be explained by an increase in testosterone levels (puberty), cognitive changes and numerous changes in social relations (Wigfield, Byrnes, \& Eccles, 2006). Nevertheless, the majority of research (for review see Tremblay, 2000) has indicated a decrease from childhood on. We can assume that if we took a larger developmental frame that would include late adolescence as well we could observe a decrease after early adolescence.

As pointed out, our results show an increase in aggression in the observed developmental period in line with findings from the personality development literature, indicating that greater stability is achieved after the period of adolescence (Matthews et al., 2009).

\section{TIME DIFFERENCES}

Another focus of our research was time-related trends. Due to frequent media report of aggressive behaviour, especially in a school setting, the research question was relevant for the Slovenian context. Time-related trends showed a decrease in physical aggression and an increase in internal aggression. The decrease in physical aggression could show that physical aggression actually decreased in time, since we as a society became less tolerant of the physical types of aggression (e.g. a zero-tolerance policy for violence in schools). Physical aggression is easily observed by others (e.g. parents, teachers) and easily sanctioned. But we have to be careful since this does not mean that aggression disappeared; it could have simply changed its form into more subtle and hard to measure types (e.g. internal aggression or indirect aggression) indicating the heterotypic nature of aggression as a trait (Donnelan \& Robins, 2009). Some researchers (Koops \& Orobio de Castro, 2004) for instance argue that there is no such thing as late starters in aggressive behaviour - late aggression simply means that the aggression was in a way repressed before (in a form of negative emotionality or intense 
feelings of guilt). This is in a way also represented in our results, since the increase in time is significant in both age groups in internal aggression. Internal aggression represents the aggression directed at one self in the form of bad moods, negative emotions and guilt (Connor, 2002), which can also be related to anxiety. Also, as established by Twenge (2000) and confirmed with our national analyses on anxiety-related time trends (Kozina, 2014), children's average level of anxiety appears to have been increasing in time. The shift from external direct aggression to internal aggression can also be explained by increasing overall community threats. The time from 2007 to 2011 is the time of a world economic crisis, the crisis of the EU and the euro. These overall threats and economic conditions could also be reflected in our data, since also in Slovenia the rates of unemployment are rising; the time from 2007 on is a time of high social insecurity, political crisis and lack of future prospects. This also relates to the increase in internal aggression in four years' time being slightly greater in 14-year-olds compared to 10-year-olds. It could be that the older age group is more under the influence of the crisis and the changing society (perceived insecurities in their parents, the media, etc.). Nevertheless, we have to point out that the effect sizes regarding time-related trends are small; therefore in order to draw a valid conclusion we would have to monitor aggression in a longer period and in more countries.

\section{CONCLUSIONS}

The present study with its cohort research design added to the understanding of development of general trait aggression, and specific types of aggression, by introducing age differences in large representative samples that cannot be explained by generation differences in the Slovenian context. Longitudinal studies show stability in aggression through the life span and at the same time cross sectional studies report significant age differences in aggression between different age groups. Since longitudinal cohort studies are rarely conducted on representative samples of such a large size, the results are of great importance. Additionally, the paper offers an analysis of developmental trends of different types of aggression, which give a more comprehensive view of the subject matter. Due to both the developmental and time-related increase in aggression, early aggression intervention is supported. The overall aggressiveness of students in a classroom has been found to increase the aggressiveness of other students in that class (Barth, Dunlap, Dane, Lochman, \& Wells, 2004; Kim, Hetherington, \& Reiss, 1999), indicating the great importance of aggression prevention. Aggressiveness in the period of early adolescence needs to be observed carefully, since early aggressiveness has a reasonable chance of turning into severe antisocial aggressiveness in a young adult in the form of criminal behaviour, abuse and physical aggression and is transmitted across generations (Huesmann et al., 1984).

\section{LIMITATIONS}

Despite the important contributions this investigation makes to the understanding of developmental and time-related differences in aggression, the study is not without limitations. In particular, the scale used for measuring aggression is relatively new and has not been used in this type of studies before. Future research based on a longitudinal design is needed to establish whether these differences in fact show a developmental increase in general aggression. In order to draw conclusions about time-related trends, research should focus on expanding the time frame and include international comparisons as well. At this point the findings are representative for the Slovenian context and only for two selected developmental periods and for the time frame of four years. Future international comparisons would be great contributions for the study of trait aggression development with implications for practice.

\section{RefERENCES}

Alsaker, F., \& Dick-Niederhauser, A. (2008). Depression and suicide. In S. Jackson \& L. Goossens (eds.), Handbook of adolescent development: European perspectives (pp. 308-336). Hove, UK: Psychology Press.

Archer, J., \& Coyne, S. M. (2005). An integrated review of indirect, relational, and social aggression. Personality and Social Psychology Review, 9, 212230. doi: 10.1207/s15327957pspr0903_2

Barth, J. M., Dunlap, S. T., Dane, H., Lochman, J. E., \& Wells, K. C. (2004). Classroom environment influences on aggression, peer relations, and academic focus. Journal of School Psychology, 42, 115-133. doi: 10.1016/j.jsp.2003.11.004

Bjorkqvist, K., Lagerspetz, K. M. J., \& Kaukiainen, A. (1992). Do girls manipulate and boys fight? Developmental trends in regard to direct and indirect aggression. Aggressive Behavior, 18, 117-127.

Cairns, R. B., Cairns, B. D., Neckerman, H. J., Ferguson, L. L., \& Gariepy, J. L. (1989). Growth and aggression: 1 . Childhood to early adolescence. Developmental Psychology, 25, 320-330.

Card, N. A., Stucky, B. D., Sawalani, G. M., \& Little, T. D. (2008). Direct and indirect aggression during childhood and adolescence: a meta-analytic review of gender differences, intercorrelations, and 
relations to maladjustment. Child Development, 79, 1185-1229. doi: 10.1111/j.1467-8624.2008.01184.x

Choynowski, M. (1995). Does aggressiveness have a factorial structure? Personality and Individual Differences, 18, 167-187. doi: 10.1016/01918869(94)00143-G

Connor, D. F. (2002). Aggression and antisocial behaviour in children and adolescents. Research and treatment. New York, USA: Guilford Press.

Connor, D. F., Steingard, R. J., Cunningham, J., Andreson, J. J., \& Melloni, R. (2004). Proactive and reactive aggression in referred children and adolescents. American Journal of Orthopsychiatry, 74, 139-136. doi: 10.1037/0002-9432.74.2.129

Čotar Konrad, S. (2005). Čustvena klima v družini: primerjava med slovenskimi in španskimi študenti [Emotional climate in families: comparison between Slovene and Spanish studenst]. Psihološka Obzorja, 14, 81-105.

Donnelan, M. B., \& Robins, R. W. (2009). The development of personality across lifespan. In P. J. Corr \& G. Matthews (eds.), Personality psychology (pp. 191-204). Cambridge: Cambridge University Press.

Eron, L. D., Huesmann, L. R., Brice, P., Fischer, P., \& Mermelstein, R. (1983). Age trends in the development of aggression, sex typing, and related television habits. Developmental Psychology, 19, 71-77.

Flannery, D. J., Vazsonyi, A. T., \& Waldman, I. D. (2007). The Cambridge handbook of violent behaviour and aggression. Cambridge: Cambridge University Press.

Goossens, L. (2008). The many faces of adolescent authonomy: parent-adolescent conflict, behavioural decision-making, and emotional distancing. In S. Jackson \& L. Goossens (eds.), Handbook of adolescent development (pp. 135-153). Hove and New York: Psychology Press.

Hudley, C. (1993). Comparing teacher and peer perception of aggression: An ecological approach. Journal of Educational Psychology, 82, 377-384.

Huesmann, L. R. (1994). Aggressive behaviour - current perspectives. New York \& London: Plenum Press.

Huesmann, L. R., Dubow, E. F., \& Boxer, P. (2009). Continuity of aggression from childhood to early adulthood as a predictor of life outcomes: Implications for the adolescent-limited and life-coursepersistent models. Aggressive Behavior, 35, 136149. doi: 10.1002/ab.20300

Huesmann, L. R., Eron, L. D., Lefkowitz, M. M., \& Walder, L. O. (1984). Stability of aggression over time and generations. Developmental Psychology, 20, 1120-1134.

Japelj Pavešić, B., Svetlik, K., Rožman, M., \& Kozina, A. (2008). Matematični dosežki Slovenije v raziskavi TIMSS 2007 [Mathamatical achievement in TIMSS 2007]. Ljubljana: Pedagoški Inštitut.
Japelj Pavešić, B., Svetlik, K., \& Kozina, A. (2012). Znanje matematika in naravoslovja med osnovnošolci $v$ Sloveniji in po svetu [Mathematical and Science achievement in elementary school in Slovenia and abroad]. Ljubljana: Pedagoški Inštitut.

Koops, W., \& Orobio de Castro (2004). Development of aggression: causes and trajectories. In G. Bruinsma, H. Elffers, \& J. de Keijser (eds.), Punishment, places, and perpetrators : developments in criminology and criminal justice research (pp. 232-247). Devon, UK: Willan Publishers.

Kozina, A. (2014). Developmental and time-related trends of anxiety from childhood to early adolescence: Two-wave cohort study. European Journal of Developmental Psychology, 11, 546-559. doi: 10.1080/17405629.2014.881284

Kozina, A. (2016). Does Anxiety Lead to Aggression - a Test of a Model on Slovenian Samples? International Psychology Bulletin, 20, 43-48.

Kozina, A. (2013). The LA aggression scale for elementary school and upper secondary school students: examination of psychometric properties of a new multidimensional measure of self-reported aggression. Psihologija, 46, 245-259. doi: 10.2298/ PSI130402003K

Kim, J. E., Hetherington, E. M., \& Reiss, D. (1999). Associations among family relationships, antisocial peers, and adolescents' externalizing behaviours: gender and family type differences. Child Development, 70, 1209-1230.

Loeber, R., \& Hay, D. (1997). Key issues in the development of aggression and violence from childhood to early adulthood. Annual Review of Psychology, 48, 371-410.

Marjanovič Umek, L., \& Zupančič, M. (2004). Razvojna psihologija [Developmental Psychology]. Ljubljana: Znanstvenoraziskovalni inštitut Filozofske fakultete.

Matthews, G., Deary, I. J., \& Whiteman, M. C. (2009). Personality traits. Cambridge, England: Cambridge University Press.

Moffitt, T. E. (1993). Adolescence-limited and life-course-persistent antisocial behavior: A developmental Taxonomy. Psychological Review, 100, 674-701.

Mugnaioni Lešnik, D., Koren, A., Logaj, V., \& Brejc, M. (2008). Nasilje $v$ šolah: Konceptualizacija, prepoznavanje in modeli preprečevanja in obvladovanja [Violence in schools: conceptiualization, recognitions and prevention models]. Ljubljana: Šola za ravnatelje.

Musek, J. (1994). Psihološki portret Slovencev [Psychological profile of Slovenes]. Ljubljana: Sophia.

Olweus, D. (1979). Stability of aggression patterns in males: A review. Psychological Bulletin, 86, 852-875.

Overton, W. F. (2004). Trajectories of physical aggression from toddlerhood to middle childhood. Oxford, England: Blackwell Publishing. 
Popp, U. (2003). Nasilje v šoli in koncepti njegovega preprečevanja [Violence prevention in schools]. Sodobna Pedagogika, 52, 26-41.

Romano, E., Tremblay, R. E., Boulerice, B., \& Swisher R. (2005). Multilevel correlates of childhood physical aggression and pro social behaviour. Journal of Abnormal Child Psychology, 33, 565-578. doi: 10.1007/s10802-005-6738-3

Small, M., \& Terrick, K. (2001). School violence: An overview. Juvenile Justice Bulletin, 8, 3-12.

Tomori, M., Kienhorst, C. W., de Wilde, E. J., \& van den Bout, J. (2001). Suicidal behaviour and family factors among Dutch and Slovenian high school students: a comparison. Acta Psychiatria Scandinavia, 104, 198-203.

Tremblay, R. E. (2000). The development of aggressive behaviour during childhood: What have we learned in the past century? International Journal of Behavioural Development, 24, 129-141. doi: 10.1080/016502500383232

Tremblay, R. E., Nagin, D. S., Séguin, J. R., Zoccolillo, M., Zelazo, P. D., Boivin, M., Pérusse, D., \& Japel, C. (2004). Physical aggression during early childhood: Trajectories and predictors. Pediatrics, 114, 43-50.

Twenge, J. M. (2000). The age of anxiety? Birth cohort change in anxiety and neuroticism. Journal of Personality and Social Psychology, 79, 1007-1021. doi: 10.1O37//OO22-3514.79.6.1007

Vitaro, F., Brendgen, M., \& Barker, E. D. (2006). Subtypes of aggressive behaviours: A developmental perspective. International Journal of Behavioural Development, 30, 12-19. doi: 10.1177/0165025406059968

Vršnik Perše, T., Kozina, A., \& Rutar Leban, T. (2011). Negative school factors and their influence on math and science achievement in TIMSS 2003. Educational Studies, 37, 265-276. doi: 10.1080/03055698.2010.506343

Wigfield, A., Byrnes, J. P., \& Eccles, J. S. (2006). Development during early and middle adolescence. In P. A. Alexander \& P. H. Winne (eds.), Handbook of educational psychology (pp. 87-113). Mahwah, New Jersey, \& London: Lawrence Erlbaum Associates Publishers. 